\begin{tabular}{|c|c|c|c|}
\hline KULTURA & $\begin{array}{l}\text { POLSKA } \\
\text { KOMITET } \\
\text { INSTYTU }\end{array}$ & $\begin{array}{l}\text { AKADEMIA NAUK } \\
\text { SOCJOLOGII } \\
\text { T STUDIOW POLITYCZNYCH }\end{array}$ & ISSN 0023-5172 \\
\hline & 15 , nr 3 & RCHIWUM I & PUWKUIE \\
\hline
\end{tabular}

MARTA KARKOWSKA

Instytut Filozofii i Socjologii PAN

\title{
EUROPEJSKIE ARCHIWA DANYCH JAKOŚCIOWYCH
}

Kwestie związane $z$ gromadzeniem, przechowywaniem i ponownym wykorzystaniem materiałów $z$ badań jakościowych prowadzonych w naukach społecznych jeszcze do niedawna były w Polsce poruszane rzadko i znajdowały się raczej na marginesie niż w centrum zainteresowań badaczy (Filipkowski 2005). W ciągu ostatnich kilku lat sytuacja zaczęła jednak ulegać zmianie. Wynika to nie tylko z coraz większej liczby prowadzonych badań i coraz obszerniejszych zasobów danych powstających w ich wyniku. Równie istotne okazują się potrzeby badaczy przekonanych o tym, że rozwój poszczególnych dyscyplin wymaga większego niż dotychczas zwrócenia się ku własnemu dziedzictwu, dbałości o jego zachowanie i konieczność szerszego wykorzystania istniejących zasobów. Pytania, jakie nasuwają się obecnie, dotyczą więc już nie tylko „po co” archiwizować dane jakościowe, ale też $\mathrm{w}$ jaki sposób to robić $\mathrm{i}$ jakie rozwiązania mogą okazać się optymalne wobec lokalnych warunków i potrzeb.

Podobne zagadnienie były i są tematem debat $\mathrm{w}$ większości krajów europejskich i pozaeuropejskich. W ich wyniku rozpoczęto kolejne projekty, a nawet zainicjowano budowę różnego rodzaju struktur, mających na celu zachowanie, zebranie (lub choćby skatalogowanie), a następnie udostępnianie szerszemu gronu badaczy istniejących materiałów. W rezultacie powstały wyspecjalizowane w tej dziedzinie instytucje naukowo-badawcze. Choć różnią się one między sobą zarówno sposobem organizacji, wielkością, jak i zasięgiem oraz charakterem podejmowanych działań, ich doświadczenia mogą okazać się nieocenione przy przeprowadzaniu podobnych projektów w polskich warunkach. 


\section{SPECYFIKA ARCHIWIZACJI DANYCH JAKOŚCIOWYCH}

Pierwsze pytanie, jakie należy postawić w tym miejscu, dotyczy tego, jak rozumieć termin „dane jakościowe” w kontekście prac archiwizacyjnych w Polsce. Czy wobec granic między dyscyplinami naukowymi, wobec specjalizacji samych badaczy rozstrzygający winien być tu charakter badania, jego cele lub sposób prowadzenia? A może wobec tendencji do podziału na badania jakościowe i ilościowe (np. Konecki 2013) decydować winna specyfika zebranego materiału, wykorzystana metodologia, a może pierwotny sposób jego analizy?

Tego rodzaju dylematy legły u podstaw większości archiwów, co pokazuje choćby przykład brytyjskiego UK Data Archive. Jak zaznacza Loise Corti, jedna z badaczek tej instytucji, w ostateczności najbardziej korzystne okazało się przyjęcie definicji najszerszej. W jednej ze swoich prac autorka ta stwierdza: „Z definicji za «jakościowe» uznaje się wszelkie materiały badawcze, które są zbierane w ramach studiów nad człowiekiem i które nie zostały przekształcone w wartości liczbowe (np. w arkusz kalkulacyjny, bazę danych lub oprogramowania statystycznego)" (Corti 2011). W tym drugim przypadku stają się one „ilościowe”. Autorka podkreśla przy tym, że w wypadku brytyjskiej instytucji definicja terminu „dane jakościowe” jest bardzo rozległa i dotyczy szeroko rozumianych badań społecznych, obejmuje „wielość metod i narzędzi mającego na celu odpowiedź na zadane pytania badawcze" (Corti 2011). W efekcie do danych jakościowych zalicza się zarówno wywiady pogłębione, wywiady ustrukturyzowane, materiały z badań grup fokusowych, notatki badaczy, ich dzienniki, materiały powstałe na podstawie obserwacji, ale też bardziej prywatne notatki, nagrania ze spotkań (dźwiękowe, filmowe) czy odpowiedzi na pytania otwarte $z$ badań surveyowych.

Co ważne, według wzorców brytyjskich zarówno temat badań, jak i ich autorzy nie muszą być ściśle związani z konkretnymi naukami społecznymi (tak jak często ma to miejsce w Polsce, gdzie termin „dane jakościowe” najczęściej kojarzony jest $z$ badaniami socjologicznymi i socjologią jako dyscyplina). Przyjęcie takiej perspektywy sprawia, że nie dokonuje się podziału i nie wyróżnia badań socjologicznych, antropologicznych czy choćby etnograficznych, co zdecydowanie ułatwia przekraczanie granic między dziedzinami i dyscyplinami akademickimi. Decydujący staje się charakter czy typ pozyskanych materiałów, a zasoby archiwum wykorzystywane są przez badaczy reprezentujących bardzo różne gałęzie nauk humanistycznych, o często bardzo zróżnicowanych zainteresowaniach badawczych i różnorodnych metodach pracy.

Jak istotną może być to zaletą, pokazuje przykład zbioru określanego jako klasyczny i jeden z najcenniejszych wśród zdeponowanych w archiwum — zbiór „The Edwardians” (zob. Thompson 2000). Jego twórca Paul Thompson (2000) zauważył, iż zarówno wartość pozyskanych materiałów, jak i ich niedostatki uwidoczniły się najpełniej dopiero po latach: gdy zaczęto je wykorzystywać 
inaczej i w innych celach, niż zakładano początkowo, często analizując z perspektywy dyscyplin innych niż pierwotnie.

\section{POTRZEBA POWSTAWANIA ARCHIWÓW DANYCH JAKOŚCIOWYCH}

Choć samo zjawisko tworzenia archiwów danych jakościowych można uznać za stosunkowo nowe, to dynamiczny wzrost liczby tego rodzaju instytucji, podobnie jak przyczyny, dla których zostały powołane, czas ich założenia oraz sposób funkcjonowania, wiele mówią o zainteresowaniach i potrzebach środowisk badawczych.

O tym, jak istotną mogą pełnić rolę i jak wiele funkcji mogą przejmować $z$ biegiem czasu tego rodzaju instytucje, najlepiej świadczy historia brytyjskiego ESDS Qualidata (Corti 2011). Jego początki związane są z realizacją małego, pilotażowego badania zrealizowanego przez Paula Thompsona, a zleconego przez ERRS w 1991 roku. W jego wyniku okazało się, że aż dziewięćdziesiąt procent danych $z$ brytyjskich badań jakościowych albo już utracono, albo też były one zagrożone rozproszeniem lub zniszczeniem, zalegając w domach lub biurach naukowców. Pozostałe dziesięć procent materiałów, jak się okazało, nie spełniało podstawowych wymagań, takich jak sposób ich zabezpieczenia (bezpieczeństwo fizyczne), możliwość publicznego udostępniania, zaopatrzenie w czytelne i zrozumiałe (nie tylko dla samych autorów badań) katalogi, zadowalająca jakość zapisów, na przykład nagranych wywiadów.

Badanie Paula Thompsona pokazało, że wiele zbiorów, zwłaszcza starszych, zagrożonych było zniszczeniem oraz wymagało pilnych i zdecydowanych działań, jeśli chciano je w ogóle ocalić. Takie zagrożenie potwierdziło zniszczenie danych z klasycznych brytyjskich badań realizowanych w Banbury z 1974 roku, a także badań dotyczących konfliktów na tle rasowym, realizowanych w Sparkbrook z 1967 roku. Praca Thompsona ujawniła też, że sytuacja jest już tak zła, iż można jedynie oddalić ryzyko kolejnych zniszczeń i utraty najcenniejszych materiałów. Te wnioski stały się podstawą powołania ESDS Qualidata, które miało być nie tylko archiwum danych jakościowych, ale też pełnić rolę biura i jednostki mającej na celu zlokalizowanie i ocenę wartości danych $z$ badań, ich skatalogowanie na poziomie kolekcji (zbioru), dopiero zaś później zorganizowanie transferu do odpowiednich archiwów w całej Wielkiej Brytanii oraz upowszechnienie wiedzy o ich istnieniu wśród naukowców i zachęcenie do ponownego wykorzystania.

Jak bliskie były te doświadczenia najnowszym doświadczeniom polskim, pokazały często dramatyczne losy kolekcji będących pokłosiem klasycznych i szeroko opisywanych w literaturze badań. Choć w kwestii zagrożeń utraty najcenniejszych materiałów z badań jakościowych polscy badacze alarmowali już wielokrotnie, nie zawsze udało się zapobiec zniszczeniom. Wspomnieć tu można choćby opisane przez Hannę Palską (2005) losy materiałów z konkursów pamiętnikarskich. 
Niektóre zbiory ocalały wyłącznie dzięki zapobiegliwości i sentymentowi osób bliskich badaczom. Przykładem może być choćby historia badań przeprowadzonych przez zespół Stanisława Ossowskiego w Purdzie Wielkiej, miejscowości położonej na południu Warmii pod koniec lat czterdziestych. O okolicznościach, w jakich udało się przypadkowo odzyskać kilkusetstronnicowy zapis badań przeprowadzonych tuż po wojnie, warunkach jego przechowywania i zabezpieczeniu, a potem wydaniu $\mathrm{w}$ formie pierwszych publikacji szerzej pisał już Robert Traba (2006). W tym miejscu warto dodać, iż materiały z badań Ossowskiego posłużyły za podstawę kolejnych przedsięwzięć. W nowym tysiącleciu nowi badacze, odwołując się do poprzedników, powrócili w to samo miejsce, realizując własny projekt ${ }^{1}$.

Niestety, podobnych przykładów „odzyskania” czy w ogóle ocalenia kolejnych zbiorów wciąż jest niewiele. Choć można przypuszczać, że wciąż istnieją, rzadko udaje się je odnaleźć i zabezpieczyć. Dostęp do wielu jest też trudny lub ograniczony: nawet jeśli są przechowywane w zadowalających warunkach, w bibliotekach czy archiwach wybranych instytucji, często bywają nie tylko nieopisane i nieskatalogowane, ale też wiedza o ich istnieniu dostępna jest tylko ograniczonej liczbie osób i bywa, że zaciera się z biegiem czasu.

Gromadzeniu, zabezpieczaniu i dzieleniu się istniejącymi zasobami powstałymi w toku badań jakościowych nie sprzyja zarówno tradycja badań, brak procedur, jak i stosunek samych autorów badań (lub zespołów badawczych) do wytworzonych przez siebie materiałów. W badaniach jakościowych, zwłaszcza badaniach socjologicznych zdecydowanie częściej ceniona jest oryginalność tematu, narzędzi badawczych czy podejścia teoretycznego niż ścisła kontynuacja lub powrót do zebranych wcześniej, przez poprzedników materiałów i ich ponowna analiza. Badacze, choć chętnie przywołują i szeroko komentują ustalenia swoich kolegów, sporadycznie sięgają do wytworzonych przez nich materiałów. Dzieje się tak nawet wtedy, gdy uważają je za cenne i przydatne dla własnych projektów i analiz.

Sami autorzy badań rzadko szerzej udostępniają pozyskane i opracowane przez siebie dane. Praktyka taka w zasadzie nie występuje, a jeśli zdarza się, to uznawana jest za wyraz dobrej woli autorów badań, którzy dane z przeprowadzonych przez siebie badań często traktują jak osobistą własność. Wynika to jednak nie tyle $z$ ich stosunku do owoców własnej pracy, ile głównie $z$ braku procedur dotyczących postępowania z materiałami, które pozostają u badaczy, nawet jeśli projekt badawczy już został zakończony, w jego wyniku pojawiły się

\footnotetext{
${ }^{1}$ Badania te stały się podstawą dwóch pierwszych publikacji z serii Historia i Pamięć Polsko-Niemieckiego Pogranicza. Warmińska Purda: t. 1: Przeszłość zapamiętana. Narracje z pogranicza (Traba, Sakson 2007); t. 2: Purda 1900-2006. Portret wsi / Gross Purden 1900-2006. Das Portrait eines Dorfes (Kardach, Pilecki, Traba 2008). Informacje na temat projektu można znaleźć na stronie internetowej (http://www.cbh.pan.pl/index.php?option $=$ com_content\&view $=$ article\& $\mathrm{id}=187$ :historia-i-pami-polsko-niemieckiego-pogranicza-warmiska-purda-\&catid $=23 \&$ Itemid $=8$ 2\&lang $=\mathrm{pl}$ ).
} 
planowane publikacje, a całość finansowana była z funduszy publicznych. W tej sytuacji trudno się dziwić, że powrót do badań prowadzonych przed kilku, kilkunastu lub kilkudziesięciu laty i powtórna analiza zebranych materiałów, jeśli się zdarza, dotyczy najczęściej badań własnych, stanowiąc podstawę kontynuacji podjętych wcześniej tematów lub punkt wyjścia do nowych projektów.

Losem materiałów powstałych $\mathrm{w}$ toku badań jakościowych - nawet tych uznawanych za kluczowe, innowacyjne czy mające szczególne znaczenie dla dziedzictwa narodowego - często nie są dostatecznie zainteresowane również instytucje ponoszące koszty ich prowadzenia ani też te, które rozliczają kolejne przedsięwzięcia naukowe. Dla większości najważniejszą formą rozliczenia jest raport lub kolejne publikacje. Sprawa zachowania zbiorów, na podstawie których powstały, okazuje się drugorzędna lub w ogóle nie jest brana pod uwagę.

Taka sytuacja sprawia, iż kwestie związane z profesjonalną archiwizacją i ponownym wykorzystaniem szeroko rozumianych danych jakościowych $\mathrm{w}$ Polsce jeszcze do niedawna nie były dyskutowane w ogóle lub też pojawiały się na marginesie rozważań. W ostatnich latach pojawiło się jednak coraz więcej osób, projektów, instytucji, których prace są powiązane $z$ archiwizacją istniejących już zbiorów bądź z gromadzeniem nowych materiałów. Te działania często nie były i nie są ze sobą powiązane, a wielość projektów, samych praktyk archiwizacyjnych, a często także odmienność celów (którymi są na przykład archiwizacja jednej lub kilku kolekcji dotyczących specyficznej tematyki) sprawia, że trudno obecnie mówić o zintegrowanej i przemyślanej strategii archiwizacji danych jakościowych.

Nie jest to specyfika Polski. Sama idea zbierania danych jakościowych, ich zachowywania i udostępniania szerszemu kręgowi badaczy w wielu krajach europejskich pojawiła się stosunkowo niedawno, często zaledwie przed kilku laty. Dla wszystkich instytucji podejmujących takie działania — zarówno tych krajowych, jak i państwowych czy narodowych - wzorem działalności jest brytyjskie ESDS Qualidata, będące częścią UK DATA Archive.

Obecnie w wielu krajach podejmowane są próby utworzenia archiwów danych jakościowych bądź też kontynuacji projektów już istniejących ${ }^{2}$. Tak dzieje się w Finlandii, Niemczech, Szwecji, Danii, Irlandii, Czechach i Szwajcarii. W wielu przypadkach projekty te stają jednak w obliczu dużych trudności, wynikających nie tylko z wciąż dużego sceptycyzmu wobec samego pomysłu archiwizacji i wtórnego wykorzystania danych jakościowych. Kluczową okazuje się kwestia stałego finansowania. Dlatego tak istotne jest nie tylko zwrócenie uwagi na konieczność archiwizowania danych jakościowych, ale też skorzystanie z doświadczeń innych i wybranie najlepszych wzorów, odpowiadających zarówno istniejącym potrzebom, jak i specyfice oraz możliwościom danego kraju.

\footnotetext{
2 http://www.wisdom.at/fodos/Datensammlungen.aspx
} 


\section{EUROPEJSKIE ARCHIWA DANYCH JAKOŚCIOWYCH - STRUKTURA I SPOSÓB ORGANIZACJI}

W zdecydowanej większości przypadków archiwa danych jakościowych powstały i powstają albo przy archiwach danych ilościowych albo stanowią część ogólnonarodowego archiwum danych społecznych. Są to instytucje nowe: o ile dane ilościowe są archiwizowane od lat sześćdziesiątych (przykładem jest UK DATA Archive), siedemdziesiątych (niemieckie ALLF) czy osiemdziesiątych (np. austriacki WISDOM), archiwa danych jakościowych liczą sobie zaledwie kilka lub kilkanaście lat. Początki najstarszego, brytyjskiego Qualidata sięgają 1994 roku. Powstało ono jako część UK Data Archive i przyjęło nazwę ESRC Qualitative Data Archival Resource Centre. W latach dziewięćdziesiątych powstało także archiwum danych jakościowych w Finlandii, funkcjonujące obecnie w ramach Finlands samhällsvetenskapliga dataarkiv (FSD) ${ }^{3}$. W innych krajach Europy Zachodniej archiwa danych jakościowych powstały w nowym tysiącleciu. Na przykład w Austrii dane z badań jakościowych systematycznie gromadzone i udostępniane są od 2008 roku. Taką działalnością zajmuje się ośrodek, który powstał w latach osiemdziesiątych i wcześniej przechowywał i udostępniał wyłącznie dane ilościowe.

Wszystko to dowodzi nie tylko dostrzeżenia potrzeby archiwizacji badań jakościowych, dynamicznie rozwijających się w ostatnich latach, ale też swoistej przewagi badaczy stosujących w swojej pracy metody i techniki ilościowe w badaniach społecznych, ich zaawansowania w wypracowywaniu procedur dokumentacji, przechowywania i udostępniania istniejących już materiałów z badań prowadzonych w ramach instytucjonalnych. Nie dziwi więc, iż większość projektów mających na celu archiwizację danych jakościowych realizowana jest przy istniejących już archiwach danych ilościowych. Co ciekawe, nowe jednostki nie zawsze stają się $\mathrm{w}$ związku $\mathrm{z}$ tym formalnie odrębną instytucją. Tak było choćby w przypadku brytyjskiego Qualidata, które nie zostało powołane jako odrębne archiwum, ale jako biuro i jednostka działania UK Data Archive (Corti 2011).

Okazuje się też, iż sprawdzać się mogą i inne rozwiązania. Wyjątkowym przykładem jest to, które zastosowano w Szwajcarii. Aż do 2009 roku nie było tam żadnej instytucji państwowej odpowiedzialnej za archiwizację danych jakościowych wytworzonych w naukach społecznych (Kleiner i in. 2010/2011). Impulsem do jej powstania okazały się doświadczenia kilkorga socjologów, którzy borykając się z problemem dostępu do potrzebnych im danych wypracowali ramy dla powstania instytucji, jaką jest obecnie współpracujące z ważniejszymi, szwajcarskimi ośrodkami akademickimi centrum nazwane FORS ${ }^{4}$. Jak zauwa-

\footnotetext{
3 Jego nazwa na język angielski tłumaczona jest jako Finnish Social Science Data Archive.

${ }^{4}$ Nazwa FORS na język angielski została przetłumaczona jako Swiss Centre of Expertise in the Social Sciences.
} 
żają jego twórcy, zasadnicze znaczenie miało tu kilka czynników. Pierwszym była wyjątkowość Szwajcarii jako państwa tworzonego przez kraje związkowe - kantony, mające własne ustawodawstwo, władzę wykonawczą i sądownictwo. Drugim bardzo ważnym elementem okazała się popularność archiwów prywatnych, często trudno dostępnych i różnie katalogujących swoje zbiory. Trzecim było to, że mimo wzrostu liczby badań jakościowych na poziomie federalnym wciąż nie było ośrodka, który koordynowałby tego rodzaju działania, często prowadzone przez bardzo różnych badaczy i różne instytucje. Wszystko to sprawiło, że za najważniejsze uznano nie samo zachowanie zgromadzonych już materiałów z badań, ale podjęcie współpracy między instytucjami i badaczami, pozwalającej na wypracowanie i promowanie najlepszych praktyk, procedur i metod archiwizacyjnych, a w konsekwencji - stworzenie i rozwijanie szwajcarskiej bazy danych, gromadzącej informacje na temat istniejących zasobów. Co ważne, taka kooperacja była i jest tu postrzegana przede wszystkim jako aktywna sieć wzajemnych powiązań i wsparcia dla działań związanych nie tylko $z$ zachowaniem, ale też ponownym wykorzystaniem zgromadzonych danych. W ten sposób wypracowano model działań nie tyle powielający inne wzorce, ile wykorzystujący lokalne uwarunkowania i szwajcarską specyfikę.

Przykład Szwajcarii pokazuje, że realizacja postulatu zabezpieczania, przechowywania i ponownego wykorzystania materiałów zebranych w ramach szeroko rozumianych badań jakościowych w praktyce może prowadzić do wypracowania unikalnych rozwiązań, jednak zawsze potrzebuje instytucjonalizacji. Pokazują to przykłady innych krajów europejskich. W większości z nich tego rodzaju przedsięwzięcia wciąż mają status projektu lub dopiero zyskują kształty instytucjonalne. Przykładem może być niemiecki projekt ALLF (Archiv für Lebenslaufforschung), który dopiero niedawno zyskał nową podmiotowość. ALLF rozpoczął swoją działalność od współpracy z Archiwum Danych Nauk Społecznych (DAS) Instytutu CSA Leibniza, powstał w wyniku „ogólnokrajowego studium wykonalności archiwalnej i wtórnego wykorzystania danych jakościowych" za lata 2003-2005. Obecnie, po kolejnych zmianach w zakresie zadań i sposobu finansowania, archiwum to zapewnia szeroki dostęp do cyfrowych danych i dokumentacji będących wynikiem empirycznych projektów badawczych, w celu ich wtórnego wykorzystania w dziedzinie badań i nauczania. Podobne przedsięwzięcie realizowane jest od 2008 roku w Irlandii i nosi nazwę Irish Qualitative Data Archive (IQDA). W przeciwieństwie do przykładu austriackiego ma ono wciąż status projektu (jest finansowane w ramach PRTLI4).

Ciekawe okazuje się również samo usytuowanie archiwów jakościowych w systemach naukowych przyjętych na Wschodzie i na Zachodzie Europy. W krajach zachodnioeuropejskich najczęściej archiwa takie powstają albo jako instytucje działające przy uniwersytetach albo funkcjonują $\mathrm{w}$ ramach uniwersytetów. Przykładem może być UK DATA Archive, które powstało i działa przy Uniwersytecie w Essex; Archiv für Lebenslaufforschung (ALLF), które jest częścią eScience Center na Uniwersytecie w Bremie; czy wspominane już ir- 
landzkie IQDA, które funkcjonuje przy Irlandzkim Uniwersytecie Narodowym w Maynooth ${ }^{5}$. Bywa, że archiwa tego rodzaju powstają też w ramach instytutów badawczych, najczęściej związanych z uniwersytetami, jednak organizacyjnie stanowią odrębne jednostki. Przykładem może być austriacki Wiener Institut für sozialwissenschaftliche Dokumentation und Methodik (WISDOM), który współpracuje $z$ Wydziałem Nauk Społecznych Uniwersytetu w Wiedniu ${ }^{6}$.

Odmienne rozwiązania przyjęto w niektórych krajach Europy Środkowo-Wschodniej. Tu archiwa danych jakościowych tworzone są raczej przy samodzielnych i ogólnokrajowych pozauniwersyteckich instytucjach naukowych, takich jak Akademie Nauk. Przykładem może być OSA (Open Society Archives), działające przy Węgierskiej Akademii Nauk w Budapeszcie ${ }^{7}$, inicjatywa utworzenia archiwum danych jakościowych przy Instytucie Socjologii Czeskiej Akademii Nauk (Čížek 2010/211), a także Archiwum Danych Jakościowych (ADJ), tworzone obecnie przy Instytucie Filozofii i Socjologii Polskiej Akademii Nauk ${ }^{8}$ w ramach projektu finansowanego przez Narodowy Program Rozwoju Humanistyki. Przyjęcie takich rozwiązań (choć zapewne wynikające $z$ historycznych uwarunkowań) okazuje się bardzo istotne nie tylko ze względu na specyfikę instytucji naukowych, ale też wypracowane już formy współpracy w ramach Akademii Nauk. W przyszłości mogą okazać się one pomocne właśnie w rozwoju archiwistyki badań jakościowych i zachowania często już historycznych materiałów.

\section{ARCHIWUM DANYCH JAKOŚCIOWYCH}

Ostatni z przywołanych wyżej przykładów - Archiwum Danych Jakościowych - pokazuje, jak wiele trudności towarzyszy powstaniu archiwum tego rodzaju w polskich warunkach. Początki ADJ wiążą się z powstaniem Archiwum Danych Społecznych (ADS). ADS swoją działalność rozpoczęło w 2004 roku - jako wspólne przedsięwzięcie Instytutu Studiów Społecznych UW i Instytutu Filozofii i Socjologii PAN. Jego celem było stworzenie dwóch jednostek: archiwum danych jakościowych i archiwum danych ilościowych, które przyjęło nazwę Archiwum Danych Społecznych (ADS). Od tego czasu drugie z nich zgromadziło znaczące, często kluczowe dla nauk społecznych dane z badań realizowanych na poziomie ogólnopolskim. Pierwszemu przez wiele lat, mimo wielu wysiłków (np. Artura Kościańskiego, Hanny Palskiej), udało się zgromadzić jedynie nikły zasób danych. Wynikało to głównie z problemów związanych z dostępnością danych jakościowych gromadzonych przez poszczególnych ba-

${ }^{5}$ National University of Ireland, Maynooth (www.iqda.ie).

6 AQUA - DAT: Archiwizacja danych jakościowych i ilościowych na Wydziale Nauk Społecznych Uniwersytetu w Wiedniu.

7 www.osaarchivum.org

8 www.ads.org.pl 
daczy i zespoły badawcze, często fatalnym stanem zachowania materiału badawczego, o czym pisała Hanna Palska (2005) i brakiem funduszy. Przeszkodą okazywały się kontrowersje dotyczące dzielenia się z innymi pozyskanym przez autorów badań materiałem, często też niechęć środowiska wobec tego rodzaju praktyk (Kościański 2005), a także brak tradycji archiwizacji badań jakościowych i konieczność dyskusji nad modelem archiwizacji, który można przyjąć w Polsce (Filipkowski 2005). Dlatego tak ważne okazało się przeprowadzenie projektu pilotażowego, który ujawnił możliwości i ograniczenia działań archiwizacyjnych prowadzonych w odniesieniu do konkretnych materiałów z badań jakościowych. Projekt ten realizowany był w ramach grantu badawczego: „Badania «rozumiejące» stylu życia: digitalizacja — archiwizacja — rewizyta metodologiczna. Pilotażowy projekt Archiwum Danych Jakościowych przy IFiS PAN" (numer projektu 11H 11 019880) i finansowany ze środków Narodowego Programu Rozwoju Humanistyki. Stał się on podstawą kolejnego przedsięwzięcia - powołania Archiwum Danych Jakościowych - które powstaje w ramach projektu „Archiwum Danych Jakościowych przy IFiS PAN” (realizowany ze środków Narodowego Programu Rozwoju Humanistyki, moduł 1.1, numer projektu 11H 12030581 ).

Oba przedsięwzięcia pozwoliły nie tylko na zabezpieczenie kilku najważniejszych zbiorów, ale też rozpoczęcie dyskusji dotyczących archiwizacji i możliwości udostępniania materiałów z szeroko pojętych polskich badań jakościowych.

\section{ARCHIWA DANYCH JAKOŚCIOWYCH — NOWE WYZWANIA I POTRZEBY}

Realizacja przywołanych wyżej dwóch polskich projektów ukazała wiele istotnych, acz wcześniej nie dostrzeganych trudności. Ujawniła też szereg odmienności związanych $z$ tworzeniem archiwów danych ilościowych i danych jakościowych. Chciałabym wspomnieć jedynie o kilku.

Najważniejszy okazał się nie tylko odmienny charakter danych ilościowych i jakościowych, ale przede wszystkim odmienność form ich gromadzenia i przechowywania. Techniki zbierania, zapisu czy przygotowywania do archiwizacji zbiorów danych ilościowych podlegają powszechnie stosowanym standardom. Dzięki temu te materiały mogą być stosunkowo łatwo włączone do istniejących już zasobów archiwów czy baz danych (oczywiście jeśli spełniają określone warunki). Ich udostępnianie szerszemu gronu badaczy w ramach archiwum dysponującego już odpowiednią infrastrukturą nie nastręcza większych kłopotów, a jeśli już to problemem okazuje się na przykład przeformatowanie danych.

W przypadku powstawania nowego archiwum danych jakościowych problemy okazały się zdecydowanie odmienne. Istotne były kwestie techniczne - większość badań musiała zostać zarchiwizowana $\mathrm{w}$ formie cyfrowej, ponieważ dotychczasowy zapis (na papierze, w postaci wywołanych zdjęć, zapisów na taśmie magnetofonowej) często uniemożliwiał wykorzystanie zebranych materiałów przez szersze grono badaczy. Konieczne stało się zeskanowanie 
materiałów takich jak transkrypcje, zdjęcia, opisy itp., ale też nowy zapis, na przykład w formacie mp3, starych nagrań magnetofonowych, ich „czyszczenie” i poprawienie ich jakości. Działania te wymagały nie tylko sporo wysiłku, ale też konkretnych nakładów finansowych.

Istotną przeszkodą okazało się też to, iż podczas badań jakościowych materiały były gromadzone przede wszystkim z myślą o ich wykorzystaniu przez dany zespół, często przez jednego badacza lub wąskie grono współpracowników; jedynie w ramach konkretnego projektu. W efekcie sposób ich przechowywania nie tylko nie sprzyjał dalszym pracom archiwizacyjnym (wiele materiałów zostało zagubionych lub uległo fragmentaryzacji), ale też wymagał uporządkowania i często nowego opisu.

Nie mniej ważne stało się samo stworzenie i udostępnienie zapisu materiałów w formie cyfrowej. ADJ, podobnie jak większość innych tego rodzaju archiwów, gromadzi dane jedynie $\mathrm{w}$ formie cyfrowej i nie przejmuje całych zbiorów - te powracają do właścicieli. Taka praktyka została przyjęta $\mathrm{w}$ prawie wszystkich wspominanych wcześniej archiwach. Większość z nich nie ma możliwości gromadzenia oryginalnych materiałów i rzadko stają się ich właścicielem, choć oczywiście są w stanie wskazać, skąd pochodzą zdigitalizowane zbiory i gdzie przechowywane są materiały, takie jak pierwotne nagrania wywiadów czy papierowa dokumentacja. Dzięki temu zachowane zostają prawa właściciela, a dostęp do zgromadzonych materiałów jest nie tylko łatwiejszy i bardziej powszechny, ale też, paradoksalnie, sprzyja to ochronie poufnych informacji i kontroli sposobu wykorzystywania danych.

Przykładem i dla wielu wzorem do naśladowania jest znowu brytyjskie ESDS Qualidata, które udostępnia swoje zasoby poprzez portal UK Data Service. Dzięki temu rozwiązaniu możliwe jest nie tylko przeglądanie katalogów, ale też wyszukiwanie i pobieranie danych. $Z$ pełnych zasobów danego zbioru można korzystać dopiero po zalogowaniu, w czasie rzeczywistym. Dane znajdujące się w systemie gromadzone są w różnych formatach (PDF, Excel, Word, RTF), co pozwala zapoznać się nie tylko z tradycyjnymi transkrypcjami wywiadów, ale również z zapisami audio i wideo, niekiedy też dotrzeć na przykład do zdjęć czy grafik. Większość kolekcji obejmuje także narzędzia badawcze, opisy metodologii badań, wywiady z badaczami.

Archiwa mogą $\mathrm{w}$ różny sposób ograniczać dostęp do wybranych danych. Mogą to być ograniczenia czasowe, wynikające $z$ decyzji autora badań, który chce swój zasób wyłączyć z użytku przez pewien okres, na przykład do czasu ukazania się publikacji. Obostrzenia mogą też dotyczyć dostępu do wybranych danych czy sposobu ich wykorzystania - wiele archiwów zastrzega, że ich dane nie mogą być użyte w celach komercyjnych pod groźbą sankcji prawnych.

Cyfrowa archiwizacja danych $z$ badań jakościowych ma też inne znaczenie. Dane zgromadzone $\mathrm{w}$ formie papierowej, zapisy $\mathrm{z}$ badań przeprowadzonych przed kilkunastu lub kilkudziesięciu laty obecnie stanowią już nie tylko dokumentację dawnych projektów badawczych, ale też są znakomitym źródłem 
historycznym, często wzorem rzetelnych badań i dobrych praktyk. Niestety, wiele $z$ nich po latach trudno odczytać. $W$ takich wypadkach nadanie im nowej, cyfrowej postaci i zapisanie na nowych nośnikach jest jedynym sposobem ich ocalenia. Umożliwia też ich nowe wykorzystanie - i nie chodzi tu wyłącznie o powielanie $\mathrm{w}$ dowolnej ilości czy rozpowszechnianie wiedzy o ich istnieniu. Zapis na papierze, niekiedy trudny do odczytania dzięki powiększeniu, wyostrzeniu, rozjaśnianiu lub przyciemnieniu może zostać odczytany na nowo. Ale nie tylko. Techniki i oprogramowanie OCR (Optical Character Recognition) zarówno pozwalają na odczytanie poszczególnych znaków, a nawet całego tekstu, jak i umożliwiają jego dalszą obróbkę (np. przygotowanie do publikacji). Nagrania $z$ wywiadów, na przykład zapisane na taśmach magnetofonowych, mogą być utrwalone w nowych formatach, co pozwala nie tylko na ich ponowne, wielokrotne, niemal nieograniczone odtwarzanie, ale też na takie przygotowanie plików dźwiękowych, by możliwa była ich dalsza obróbka: zarówno wyciszenie szumów, niepożądanych zakłóceń, jak i wzmocnienie wybranych głosów, wyeksponowanie tych dźwięków, które mogą okazać się istotne dla analizy zebranego materiału.

Równie istotne okazują się także inne możliwości, jakie niesie ze sobą nadanie starym materiałom nowej formy. Wśród wielu $z$ nich wskazać należy zabezpieczenie danych, ich cyfrowa obróbka umożliwia nie tylko kompresję danych, ale także zabezpieczenie przed ingerencją użytkowników (np. w udostępniany tekst). Wspomnieć też należy o uporządkowaniu materiału. Digitalizacja pociąga za sobą konieczność nadania różnych, jednak uporządkowanych sygnatur, zastosowania odpowiedniego klucza podziału pozyskanych materiałów. W ten sposób możliwe jest nie tylko uchwycenie pierwotnych pomyłek, ale też wskazanie, jak wykorzystywane były zgromadzone zasoby, które materiały cieszyły się większym, a które mniejszym zainteresowaniem, jakie narzędzia okazały się najbardziej przydatne. Takie możliwości ujawniła digitalizacja kolekcji z prowadzonych na przełomie lat siedemdziesiątych i osiemdziesiątych badań Andrzeja Sicińskiego. Cyfryzacja tych materiałów pokazała nie tylko pomyłki badaczy (np. dublowanie się sygnatur), pozwoliła też ustalić, ilu danych brakuje (niekiedy też jakich) oraz wskazać, które materiały uznane były za najbardziej wartościowe i które najchętniej wykorzystywano.

Warto podać tu choćby jeden przykład. Zespół Sicińskiego zgromadził materiały dotyczące 73 rodzin. Każdej z nich przyporządkowano teczkę, w której znalazły się dane, takie jak informacja o rodzinie, metryczki, życiorysy (przedstawione na podstawie wypowiedzi wybranych członków rodzin), uzupełnienie życiorysów, dzienniczki badaczy i opisy interpretowane; wszystkie były uzupełniane lub spisywane odręcznie ${ }^{9}$. W niektórych przypadkach zachowano też

${ }^{9}$ Zob. http://adj.ifispan.pl/katalog-1. Wszystkich teczek jest dużo więcej, jednak tych wskazanych przez badaczy jako bezpośrednio dotyczące rodzin badanych udało się odnaleźć 73 . Sam Andrzej Siciński (1988, s. 139) pisał o 72 teczkach. 
nagrania $z$ wywiadów na taśmach magnetofonowych, zdjęcia, a nawet wycinki prasowe. W trakcie archiwizacji okazało się jednak, iż istnieją także dodatkowe teczki z materiałami z badań (np. rozliczeniami, wstępnymi wersjami artykułów). Jedna $z$ nich zawierała coś zupełnie innego. Był to mianowicie zbiór opisów interpretowanych, przepisanych na maszynie (ich oryginalne, pisane odręcznie wersje można było często znaleźć w teczkach poszczególnych rodzin). Najwyraźniej całość była nie tylko intensywnie wykorzystywana, ale też musiała być powielona w kilku kopiach (na co wskazywały strony najwyraźniej pisane przez kalkę).

Jak pokazuje ten przykład, choć możliwość ustalenia pomyłek czy odnalezienia teczki z opisami interpretowanymi zapewne istnieje także przy tradycyjnej archiwizacji materiałów, to nowe, dokładne przejrzenie i sprawdzenie materiałów wymagane przy digitalizacji wprost to wymusiło. Wiele dała też konieczność utworzenia katalogu kolekcji, którego nie było w wersji pierwotnej (bez tego trudno byłoby udostępniać całość). Cenna okazała się sama technika systemu porządkowania całości według folderów. To ona wymusiła nowy podział materiałów i stworzenie nowej logiki układu całości, pozwalającej na dostrzeżenie różnych etapów prac i trudności, z jakimi borykali się badacze zróżnicowanej objętości teczek dotyczących poszczególnych rodzin czy pracy z materiałami różnej jakości dostarczonymi przez kilkunastu badaczy.

Prace nad digitalizacją materiałów z badań Andrzeja Sicińskiego ujawniły też wiele problemów. Najważniejsze okazały się te związane $z$ ochroną danych osób badanych, a dokładniej zastosowanie w praktyce, w stosunku do materiałów zebranych przed kilkudziesięciu laty, aktualnych rozwiązań prawnych i etycznych. $Z$ tego powodu kluczowa była procedura anonimizacji. Choć początkowo planowane było jedynie zobowiązanie użytkowników do korzystania $z$ udostępnianych materiałów zgodnie $z$ wyznaczonymi zasadami, ostatecznie przyjęto inne rozwiązanie: zakodowano albo usunięto wybrane informacje (jednak $\mathrm{w}$ taki sposób, by możliwe było zrozumienie tekstu powierzonego archiwum). I to doświadczenie znowu okazało się specyficzne - w przypadku badań Sicińskiego procedura przeprowadzona została przez archiwum. W większości krajów mających w tym względzie większe tradycje i rozległe doświadczenia obowiązek ten spoczywa na deponujących dane, najczęściej autorach badań. Taki wymóg nakłada brytyjskie ESDS Qualidata, wychodząc z założenia, iż autorzy badań najlepiej znają swój materiał i to oni najlepiej go zabezpieczą. Istotne tu jest też założenie, iż badania prowadzone $z$ funduszy publicznych stanowią publiczną własność. Dlatego ważnym elementem każdego przedsięwzięcia już na etapie jego projektowania jest wskazanie, w jaki sposób pozyskane dane będą archiwizowane. Co więcej, jest to nie tylko wymóg samego archiwum, ale przede wszystkim istotna pozycja we wnioskach finansowanych $z$ funduszy publicznych.

Nieco inne rozwiązania stosują archiwa, które często same muszą borykać się z problemem anonimizacji badań. Przykładem może być węgierska OSA, 
której celem jest zabezpieczenie nie tylko nowych kolekcji, ale także materiałów z badań prowadzonych kilkanaście lub kilkadziesiąt lat wcześniej. W archiwum wypracowano reguły i wprowadzono wiele zastrzeżeń dotyczących korzystania z określonych kolekcji lub ich części, przy czym odpowiedzialnością za ujawnienie treści zachowanych danych obarczono głównie użytkowników archiwaliów ${ }^{10}$. Ograniczenia te dotyczą materiałów zawierających dane, których ujawnienie byłoby nieuzasadnionym naruszeniem prywatności lub pozwoliło na zniesławienie żywej osoby czy grupy osób; naruszałoby na przykład tajemnicę handlową czy finansową; ujawniłoby treść materiałów, do których dostęp został ograniczony na mocy decyzji sądu itd. Niestety, w wielu przypadkach archiwum trudno jest wyegzekwować te obowiązki użytkowników. Polegać ono może głównie na uczciwości osób korzystających z zasobów i odwoływać się do podpisanych zobowiązań.

Jeszcze inną kwestią jest gromadzenie zbiorów. Okazuje się bowiem, iż w krajach takich jak Wielka Brytania problemem jest nadmiar danych i konieczność ich wyboru (co pozwala na stawianie wymagań i stosowanie ścisłych procedur wobec deponowanych danych), a w krajach takich jak Węgry, Czechy czy Polska zasadnicza trudność tkwi w pozyskaniu danych (Ćížek 2010/2011).

Niezależnie od tych problemów zarówno archiwa, jak i organizacje je zrzeszające podejmują wiele działań mających na celu przezwyciężenie obaw i wyjaśnienie wątpliwości zarówno w kręgu badaczy, jak i osób, które brały, biorą lub brać będą udział w badaniach jakościowych (np. Bishop 2013). Służą temu nie tylko podręczniki archiwizacji danych jakościowych, ale też kodeksy etyczne tworzone dla badaczy i użytkowników archiwów oraz samych archiwistów (Parry, Mauthner 2004). Istotnym elementem prac archiwów okazuje się działalność edukacyjna czy promocja archiwów. Warto zaznaczyć, iż większość $z$ nich wypracowała procedury archiwizowania danych pozwalające na zastosowanie jednolitych rozwiązań często wobec bardzo różnych kolekcji. To zaś umożliwia przejęcie wielu wypracowanych już i sprawdzonych pomysłów, ich dostosowanie i ewentualnie modyfikację $\mathrm{w}$ taki sposób, by były zgodne $\mathrm{z}$ rozwiązaniami prawnymi obowiązującymi w danym kraju, przyjętymi normami i uwzględniały możliwości samych archiwów.

*

Jak pokazuje historia archiwów danych jakościowych w krajach zachodnioi wschodnioeuropejskich, ich powstanie wynikało $z$ różnych potrzeb, wiązało się z różnymi uwarunkowaniami (społecznymi, ekonomicznymi, ale też prawnymi i instytucjonalnymi). To zaś sprawiło, że archiwa te znacznie różnią się zarówno pod względem organizacyjnym, stawianych sobie celów, wreszcie samej zawartości i sposobu wykorzystywania zasobów.

10 http://www.osaarchivum.org/about-us/policies 
Ponieważ dyskusja nad rozwiązaniami, jakie można byłoby zastosować w Polsce, dopiero się rozpoczyna, na podstawie przedstawionych przykładów, omówionych problemów związanych z funkcjonowaniem archiwów danych jakościowych w Europie trudno przedstawić jednoznaczne wnioski. Wiele tematów wciąż wymaga namysłu i dyskusji, jednak już teraz warto wskazać choćby kilka rozwiązań i możliwości.

Najważniejsza jest potrzeba stworzenia swoistego rejestru zbiorów danych jakościowych, inwentaryzacji wskazującej nie tylko rodzaj materiałów, cel badań czy autorów, ale też aktualne miejsce ich przechowywania. Wobec wielości przedsięwzięć, często bardzo zróżnicowanych i kończących się wraz z krótkoterminowymi projektami, warto, by choćby ta kwestia została rozstrzygnięta jak najszybciej na poziomie ogólnopolskim. Ważne jest, by było to nie tylko jednorazowym projektem, ale dawało możliwość stałego dostępu do aktualnych, sprawdzonych informacji zarówno na temat badań zakończonych, jak i tych wciąż prowadzonych.

W perspektywie długofalowej warto wziąć pod uwagę istniejące już rozwiązania. Warto przyjrzeć się przykładowi Wielkiej Brytanii, gdzie badania, na które przeznacza się środki publiczne, uznawane są za własność całego społeczeństwa. To zaś sprawia, iż już w momencie składania wniosków o finansowanie projektów wymagane jest określenie miejsca, zasad i sposobów deponowania pozyskanych w przyszłości danych. Konieczne jest także wykazanie, iż podobne projekty, mające przynieść podobne rezultaty, nie są już finansowane ze środków publicznych. Pozwala to nie tylko na racjonalne dysponowanie funduszami, ale też ogranicza niepotrzebne mnożenie podobnych przedsięwzięć badawczych i daje możliwość uzyskania o nich informacji. To rozwiązanie wprowadzone odgórnie, przez instytucje przyznające środki na realizację badań, mogłoby być zastosowane także w Polsce.

Niezbędne jest też stworzenie warunków prawnych określających zasady działalnia archiwów danych jakościowych. Obecne rozwiązania, często wystarczające do prowadzenia badań ilościowych, w których kluczowe są dane zbiorcze, znacznie utrudniają, a niekiedy wręcz uniemożliwiają działania związane $z$ archiwizacją danych jakościowych.

Z tą kwestią wiąże się kolejna, a mianowicie konieczność omówienia i wypracowania choćby podstawowych procedur archiwizacyjnych. To zaś bez wątpienia wymaga gruntownej debaty nie tylko nad praktykami archiwizowania materiałów jakościowych, ale też rzeczowej dyskusji o kwestiach etycznych, ochronie danych czy zakresie i formach upowszechniania informacji o różnych zbiorach.

Nie ulega wątpliwości, iż archiwizowanie danych jakościowych jest konieczne, a potrzeba powstawania ośrodków długofalowo zajmujących się tą problematyką staje się paląca. Jednocześnie konieczne są działania szybkie, mające na celu ocalenie zagrożonych materiałów $z$ badań jakościowych o wartości naukowej i historycznej. Pozostaje wyrazić nadzieję, że dzia- 
łania takie nie tylko spotkają się ze zrozumieniem, ale też będą podjęte szybko.

\section{BIBLIOGRAFIA}

Binder Piotr, Filipkowski Piotr, 2010/2011, Data Sharing and Archiving Qualitative and QL Data in Poland, „IASSIST Quarterly”, t. 34, s. 71-76.

Bishop Libby, 2013, Reply to: Natasha Mauthner and Odette Parry's „Open access digital data sharing: principles, policies and practices”, „Social Epistemology Review and Reply Collective”, t. 2(8), s. 71-78.

Čížek Tomáš, 2010/2011, Archiving Qualitative and Qualitative Longitudinal Social Sciences Data in the Czech Republic, „IASSIST Quarterly”, t. 34, s. 36-37.

Corti Louise, 2011, The European Landscape of Qualitative Social Research Archives: Methodological and Practical Issues [77 paragraphs], „Forum Qualitative Sozialforschung” / „Forum: Qualitative Social Research”, t. 12, nr 3 (http://nbn-resolving.de/urn:nbn:de:0114-fqs1103117. http://www.qualitative-research.net/index.php/fqs/article/view/1746/3247).

Corti Louise i in., 2014, Managing and Sharing Research Data: A Guide to Good Practice, Sage, London.

Filipkowski Piotr, 2005, Po co archiwizować dane jakościowe i jak robia to inni, „Ask. Społeczeństwo. Badania. Metody", nr 14.

Kardach Magdalena, Pilecki Janusz, Traba Elżbieta (red.), 2008, Purda 1900-2006. Portret wsi / Gross Purden 1900-2006. Das Portrait eines Dorfes, Borussia, Olsztyn.

Kleiner Brian i in., 2010/2011, Qualititative Data Archiving in Switzerland, „IASSIST Quarterly”, t. 34, s. 77-79.

Konecki Krzysztof, 2013, Studia z metodologii badań jakościowych. Teoria ugruntowana, Wydawnictwo Naukowe PWN, Warszawa.

Kościański Artur, 2005, Archiwum społecznych danych jakościowych: potrzeby, kontrowersje, propozycje praktyczne, „Ask. Społeczeństwo. Badania. Metody”, nr 14.

Palska Hanna, 2005, O potrzebie ochrony danych jakościowych. Z doświadczeń socjologa-humanisty, „Ask. Społeczeństwo. Badania. Metody”, nr 14.

Parry Odette, Mauthner Natasha, 2004, Whose Data Are They Anyway? Practical, Legal and Ethical Issues in Archiving Qualitative Research Data, „Sociology”, t. 38, s. 139-152.

Siciński Andrzej, 1988, Styl życia w miastach polskich, w: Andrzej Siciński, Anna Wyka (oprac.), Badania „rozumiejące” stylu życia: narzędzia, IFiS PAN, Warszawa.

Thompson Paul, 1975, The Edwardians: The Remaking of British Society, Weidenfeld and Nicolson, London.

Thompson Paul, 2000, Re-using Qualitative Research Data: A Personal Account, „Forum Qualitative Sozialforschung / Forum: Qualitative Social Research", t. 1, nr 3.

Traba Robert, 2006, Historia - przestrzeń dialogu, Instytut Studiów Politycznych PAN, Warszawa.

Traba Robert, Sakson Andrzej (red.), 2007, Przesztość zapamiętana. Narracje z pogranicza, Borussia, Olsztyn.

Wyka Anna, 1993, Badacz społeczny wobec doświadczenia, Wydawnictwo IFiS PAN, Warszawa.

\section{EUROPEAN QUALITATIVE DATA ARCHIVES}

\section{Sum mary}

This article concerns the archiving of qualitative data in Europe. Its aim is to present selected models of archivization of this type of material in various European institu- 
tions, including the British ESCS (Economic and Social Data Service Qualidata) belonging to the UK Data Archive, the Austrian WISDOM (Wiener Institut für Sozialwissenschaftliche Dokumentation und Methodik), the Irish IQDA (Irish Qualitative Data Archive), the German ALLF (Archiv für Lebenslaufforschung), or the OSA (Open Society Archives) operating in the Hungarian Academy of Sciences in Budapest. The examples mentioned give rise to reflections on the need, potential, and limitations of conducting a similar project in Poland. The author discusses the results of the 'Interpretive Research into Life Styles: Digitalization, Archivization, and Methodological Revisitation' pilot project and the Archive of Qualitative Data pilot project of the Institute of Philosophy and Sociology of the Polish Academy of Sciences.

\section{Key words/słowa kluczowe}

archiving / archiwizacja; qualitative data / dane jakościowe; digitalization / digitalizacja 